spontaneously and are produced in all-ornothing fashion with carefully controlled stimulus intensities (Fig. 1c). Small changes in suprathreshold intensities can be accompanied by abrupt changes in the shape of the short-latency potentia (Fig. 1d). They are understood as combined action potentials of two large axons. Separation between the spikes of two large axons was found in some preparations where stimulus and recording site were far apart from each other indicating slightly different conduction velocities of the fibres (Fig. 1c). These short-latency spikes are the largest electrical events recorded after electrical stimulation ipsi- or contralateral to the recording site. Spikes run equally well in both directions along the cord as expected for a through-running axon system. It is reasonable to attribute the described action potentials to the two giant fibres shown by morphology. The conduction velocity of the giant fibres was determined as $1.14 \mathrm{~m} / \mathrm{s}(n=19)$ and fell in the range of $0.7-1.7 \mathrm{~m} / \mathrm{s}$.

Giant-fibre responses can be produced by mechanical stimulation of the antennae, the dorsal parts of the head, the tail, the feet and dorsolateral body walls. The strongest phasic discharges of the giant fibres were obtained from touching the head or tail. The response shows tapid habituation. Contralateral response is prevented by cutting the commissures of the ladder-like-type nerve cord near the stimulus site.

The animal displays different fast reactions when touched or pinched. One of them is a quick shortening of the body including several segments when the head or tail is stimulated. The contraction shortens the soft-body animal up to $65 \%$ of its former length in $200-500 \mathrm{~ms}$. It is assumed that the activity of the giant fibres is associated with rapid overall body movements.

The acquisition of a fast-conducting through-running giant-fibre system is a typical feature of many polysegmental invertebrates. The giant fibre system of Peripatoides shows considerable similarities to those of annelids with respect to morphology and function in relation to behavior (for comparison see [2]).

Supported by the Deutsche Forschungsgemeinschaft (grant Schu 374/1).

Received August 3, 1976

1. Horridge, G.A., in: Structure and function in the nervous systems of invertebrates, Vol I (Bullock, T.H., Horridge, G.A., eds.). San Francisco-London: Freeman 1965

2. Bullock, T.H.: Physiol. Comp. Oecol. 1, 1 (1948); Nicol, J.A.C.: Quart. Rev. Biol. 23, 291 (1948)

\title{
Erhöhung der Beutefang-Effektivität durch Librium
}

\section{R. Apfelbach}

Institut für Biologie III, Arbeitsgruppe Neuroethologie, der Universität Tübingen

Librium $^{\circledR} \quad$ (Chlordiazepoxid-hydrochlorid), ein Psychopharmakon vom Typ der Tranquilizer, wird beim Menschen allgemein zum Lösen von Angst-, Spannungs- und Aufregungszuständen eingesetzt. Von Tierversuchen, z.B. an Affen und Ratten, sind ,Zähmungseffekte" bei zuvor wilden Tieren und Abnahme der Aggression beschrieben worden $[1,3]$.

Das Beutefangverhalten des Frettchens (Putorius furo L.), eines primitiven Vertreters der Überfamilie Canoidea, besteht zu großen Teilen aus Instinkthandlungen, die durch äußere Reize ausgelöst werden und relativ starr ablaufen [2]. Librium-Konzentrationen von $1 \mathrm{mg} / \mathrm{kg}$ Körpergewicht verändern dieses Beutefangverhalten charakteristisch. Frettchen benötigen zum Suchen und Fangen von Ratten $(200-300 \mathrm{~g}$, Stamm Wistar) bis zu $60 \%$ weniger Zeit als üblich $(p<0,05$, Mann-Whitney-UTest) und wirken konzentrierter als im Normalverhalten. Die Anzahl der Bisse zum Töten der Beute verringert sich um $30 \%(p<0,05)$; die Gesamtdauer des Beutefangverhaltens sinkt um $25 \%$ $(p<0,05)$.

Librium hat damit eine größere Effektivität des Beutefangverhaltens zur Folge, was nicht zu den bekannten Befunden mit dieser Droge paßt.

\section{Eingegangen am 20. September 1976}

1. Apfelbach, R.: Neuropharmacol. 13, 11 (1974)

2. Eibl-Eibesfeldt, I.: Z. Tierpsychol. 20,705 (1963)

3. Randall, L.O., et al. : J. Pharm. Exper. Therap. $129,163(1960)$

\section{Disparlure: \\ Differences in Pheromone Perception between Gypsy Moth and Nun Moth}

\author{
D. Klimetzek, G. Loskant and J.P. Vité \\ Forstzoologisches Institut der Universität Freiburg i.Br., Germany
}

\section{K. Mori}

Dept. of Agricultural Chemistry,

The University of Tokyo, Bunkyo-ku, Tokyo, Japan

Under field conditions, males of the nun moth, Porthetria monacha, and males of the gypsy moth, $P$. dispar, respond to synthetic $(7 \mathrm{R}, 8 \mathrm{~S})-(+)$-disparlure. However, the addition of $(7 \mathrm{~S}, 8 \mathrm{R})-(-)$-disparlure in racemic proportion significantly suppresses response by $P$. dispar [1] while the racemate does not have such effects on the response by $P$. monacha.

In the absence of chemical messengers unique to the species, differences in pheromonal communication systems among sympatric insect species have been related to pheromone-pheromone combinations [2] or pheromone-kairomone systems [3]: related species share identical compounds but react to varied combinations. We present evidence that species-specificity in chemical communication might be achieved, in part, through the chiral quality of one pheromonal messenger.

Sticky traps baited with $(+)$-disparlure,

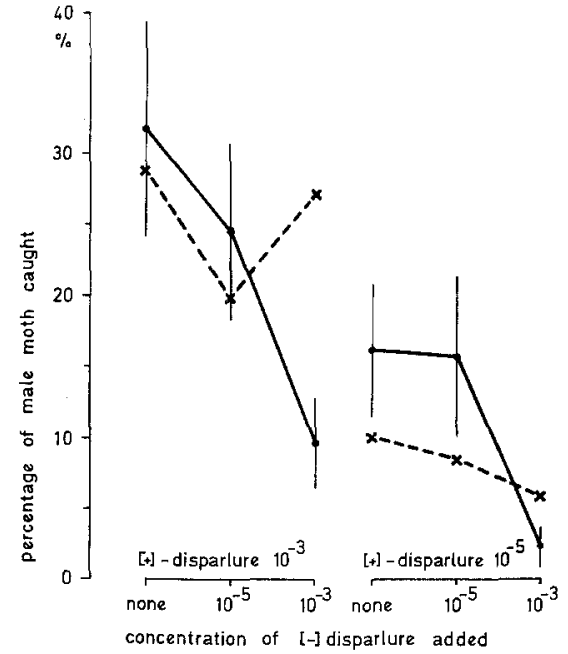

Fig. 1. Response of $P$. monacha (broken lines) and $P$. dispar (solid lines) to $(+)$ and racemic concentrations of disparlure in pentane (data for $P$. dispar from [1]; vertical lines give $95 \%$ confidence limits) 